Review Article

\title{
Advances in Properties of Rubber Reinforced Soil
}

\author{
Zhongnian Yang, ${ }^{1}$ Qi Zhang $\mathbb{D},{ }^{1}$ Wei Shi $\mathbb{D},{ }^{1}$ Jianhang Lv, ${ }^{1}$ Zhaochi Lu, ${ }^{1}$ \\ and Xianzhang Ling $\mathbb{D}^{1,2}$ \\ ${ }^{1}$ Qingdao University of Technology, Qingdao, Shandong 266033, China \\ ${ }^{2}$ Harbin Institute of Technology, Harbin, Heilongjiang 150001, China
}

Correspondence should be addressed to Wei Shi; shiwei123@qut.edu.cn

Received 27 October 2020; Revised 25 November 2020; Accepted 8 December 2020; Published 15 December 2020

Academic Editor: Castorina S. Vieira

Copyright (C) 2020 Zhongnian Yang et al. This is an open access article distributed under the Creative Commons Attribution License, which permits unrestricted use, distribution, and reproduction in any medium, provided the original work is properly cited.

\begin{abstract}
The accumulation of waste tires is a global resource and environmental problem. The landfill or incineration of tires will infiltrate toxic chemicals into the surrounding environment, which poses a serious ecological threat to the environment. A large number of studies have shown that waste tires can be used in geotechnical engineering, which provides a good idea for the recycling of waste tires. Up to now, researchers have tested the performance of soil mixed with waste tires by dynamic triaxial test, California load ratio test, unconfined compression test, direct shear test, consolidation test, and expansive force test. The results show that the stability and strength of the soil can be enhanced by adding about $20 \%$ rubber particles to the expansive soil, and the expansion, contraction, and consolidation characteristics of the expansive soil can be significantly improved. Rubber can improve the mechanical properties and deformation properties of sand. The rubber sand with a rubber content of $30 \%$ is often used as the isolation layer of middle and low buildings. However, it remains to be seen whether it is sustainable and durable to use waste tire rubber to improve soil properties and whether the chemical composition of waste tire rubber will have adverse effects on soil. So, more researchers are encouraged to look into this question. Here, we review the method and effect of rubber reinforcement technology with scrap tires and introduce the practical application of rubber reinforcement technology in engineering, such as specific engineering projects for retaining wall, road filling, shock absorption, and vibration isolation. This review will be of great significance and broad prospects for the reuse of waste tires and the development of geotechnical engineering.
\end{abstract}

\section{Introduction}

The growth of vehicles ownership is on a straight line in recent years. It is estimated that, by 2030 , the total number of vehicles in the world will reach 2 billion, and hence the number of scrapped vehicles will also increase, resulting in a large amount of waste tires every year [1]. Due to the nondegradability and unfavorable size for storage, the sites available for waste tire disposal rapidly exhaust. It is estimated that Australia produces more than 500,000 tons of waste tires every year [2]. The United States currently has 2 billion waste tires, which continue to grow at the rate of 200 million to 250 million tires per year, among which less than $10 \%$ can be recycled locally [3]. The landfill or incineration of tires will cause serious ecological threat, and the landfill of waste tires is strictly controlled [4]. Therefore, the disposal of waste tires has become a global and environmental problem. In this case, it is urgent to find new beneficial ways to recycle waste rubber $[5,6]$. Because of high tensile strength, good toughness, durability, and strong aging resistance, scrap tires have been noted by the engineering field [7]. Researchers have proved that waste tires can be applied to various civil engineering projects, such as soil reinforcement [8], road filler [9] and shock isolation [10], and slope stability [11]. As a sustainable material, rubber greatly reduces the cost of reinforcement while improving soil properties [12-16].

In recent years, the application of waste tires in geotechnical engineering has been widely studied, especially the soil reinforcement technology. The application of soil reinforcement technology can be traced back to ancient times. In ancient times, people mixed simple materials with soil to form simple reinforced soil materials [11]. Nowadays, soil 
reinforcement technology has been used in geotechnical engineering. The reinforced materials have also developed from the early natural fabrics and steel bars to geosynthetics such as geomembrane and geocell. Various soil reinforcement materials usually have the characteristics of light weight, convenient construction, low cost, and convenient production and transportation. In addition, reinforcement technology can also increase soil strength, enhance soil stability, and greatly improve soil mechanical properties [17-19].

Among soil reinforcement materials, the research and application of rubber reinforced soil have become a research hotspot [20] pointing out that rubber reinforced soil mainly refers to a new type of geotechnical material formed by mixing waste tires with other soil materials. The method of turning waste tires into geotechnical materials is to cut into fragments and strips or to ground into particles and then to mix with soil for utilization. In recent years, many researchers have tested the properties of rubber reinforced soil and found that rubber reinforcement can increase the ductility of sandy soil and improve the shear strength of soil $[12,14,21]$; through cyclic triaxial test or resonance column test, it is found that rubber reinforced soil can increase the ductility and improve the shear strength of sandy soil [22-24]. It can control the accumulation of pore water pressure and improve dynamic characteristics such as damping ratio [25-30]. For cohesive soil, rubber reinforcement can reduce its dry density and improve its compressive strength and soil stability [31-34]. Once the waste tire is mixed into the soil with the optimized content, it can not only improve the soil strength, but also reduce various adverse effects of waste tire accumulation on the environment [35].

The application of rubber reinforced soil not only has a very positive significance and broad application prospects for civil engineering, but also has a good effect on environmental protection and the promotion of "green design" [36]. In this paper, the experimental methods and progress of rubber reinforced soil are reviewed, and the effect of rubber reinforcement in different soil is summarized. The practical application of soil and the research direction of researchers provide a reference.

\section{Experiment Condition}

2.1. Rubber Type. In the current research, to optimize the soil properties, the rubber used in geotechnical engineering mainly comes from waste tires. Firstly, due to the recycling of waste tires, a large number of waste tires will cause serious adverse effects on the ecosystem [7] (see Table 1); secondly, based on the natural geotechnical properties of tire rubber, which can be mixed with soil to form rubber soil mixture, in this paper, the rubber soil mixture is called rubber reinforced soil [38].

The main chemical components of waste tires are natural rubber and synthetic rubber (such as styrene butadiene rubber and cis-1-butadiene rubber), as well as sulfur, carbon black, silicon oxide, iron oxide, calcium oxide, and other additives [39]. The waste tire fragments or particles have strong compressibility, which can increase the soil damping ratio, shear modulus, and improve the mechanical properties of soil after mixing with soil [32]. The physical and mechanical properties of rubber reinforced soil are generally related to soil type, rubber content, and rubber size.

In addition to waste tires, discarded garden hose is also characterized as rubber raw materials [37] (see Table 1). The waste garden hose was mixed with sand with respect to different content to improve its shear strength. The results show that the waste rubber tube particles make the sand mixture show obvious cohesion and improve the shear strength of sand. From the environmental aspect, this sand waste rubber tube particle material can be used in geotechnical engineering; it is also environmentally friendly.

2.2. Reinforcement Method. When waste tire rubber is used to improve soil, rubber can be mixed with soil in various forms, such as chips, debris/particle, fiber, and fine powder. According to ASTM d6270-08 (2012), the waste tire products can be divided into four categories according to their shape and size: (1) tire fragments, $50-300 \mathrm{~mm}$; (2) tire chips, usually rectangular or triangular, $12-50 \mathrm{~mm}$; (3) polished rubber, strip fiber shape, 1-2 mm; and (4) rubber powder, $0.425-2 \mathrm{~mm}$. Figure 1 shows the rubber powder under different magnification [8]. In geotechnical engineering tests, rubber debris, rubber fiber, rubber particles, and rubber powder are commonly used as rubber reinforced soil materials. Authors in [40] believed that the particle size ratio of rubber particles to soil particles determines the contact behavior of the mixture. The application of rubber with different shapes and sizes in geotechnical engineering was introduced. Because the shape of rubber particles and rubber powder is similar, the particle size is divided, while the rubber particles and rubber powder are combined into a reinforcement method.

2.2.1. Rubber Debris Reinforced Soil. At present, there are many researches on rubber debris reinforced soil, which are applied in highway construction [9], slope stability [41], lightweight backfill materials [42-44], and seismic isolation and damping materials $[45,46]$. Through direct shear test, the researchers found that the internal friction angle and shear strength of sand increased, and it was concluded that the best size and rubber content were particle size in the range of $9.5 \mathrm{~mm}-12.5 \mathrm{~mm}$ and $30 \%$ of rubber particle volume $[47,48]$. However, some scholars disagree and believe that simply changing the width of tire debris is the best way to resist the damage. Under the condition of the same tire fragment content and the same compactness, only a certain length value can make the friction angle of the mixed soil reach the maximum value [49]. And a recent study suggests that, regarding the seismic isolation capabilities of soilrubber mixtures, the optimum rubber content of $30 \%$ cannot be regarded as a constant value and depends highly on the fundamental period of the structure and the soil profile and possible resonance effects, the slenderness of the structure, the input motion's frequency and intensity, specific characteristics of the input motion (i.e., near or far field), and 
TABLE 1: Types of rubber in rubber reinforced soil.

\begin{tabular}{|c|c|c|c|c|c|}
\hline $\begin{array}{l}\text { Rubber } \\
\text { sources }\end{array}$ & $\begin{array}{l}\text { The type } \\
\text { of soil }\end{array}$ & $\begin{array}{l}\text { Optimum } \\
\text { content }\end{array}$ & Performance & Impact on the environment & Reference \\
\hline $\begin{array}{l}\text { Waste tire } \\
\text { rubber }\end{array}$ & Sand & $35 \%$ & $\begin{array}{c}\text { The expansive property of sand is reduced, } \\
\text { and the shear strength of pure sand is } \\
\text { improved }\end{array}$ & $\begin{array}{l}\text { Effectively solving the problem of } \\
\text { recycling waste tires with increasing } \\
\text { waste }\end{array}$ & [7] \\
\hline Waste hose & Sand & $10 \%-20 \%$ & $\begin{array}{l}\text { The best condition to obtain the maximum } \\
\text { friction angle }\end{array}$ & $\begin{array}{l}\text { Reducing the impact of waste hose } \\
\text { material reproduction on air and soil }\end{array}$ & {$[37]$} \\
\hline
\end{tabular}

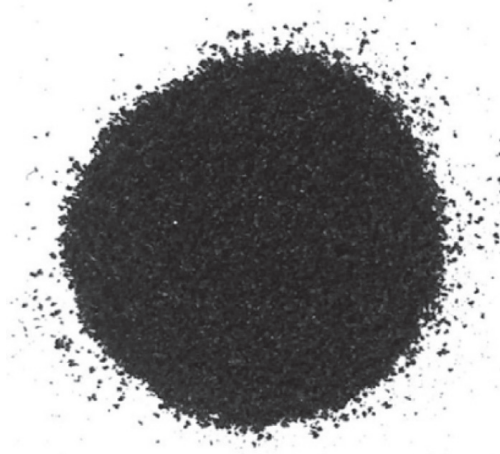

(a)

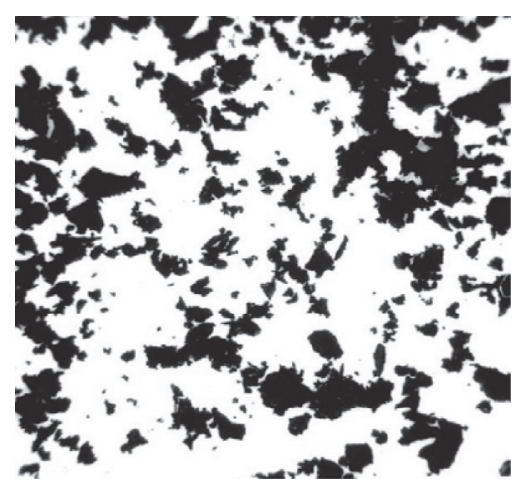

(b)

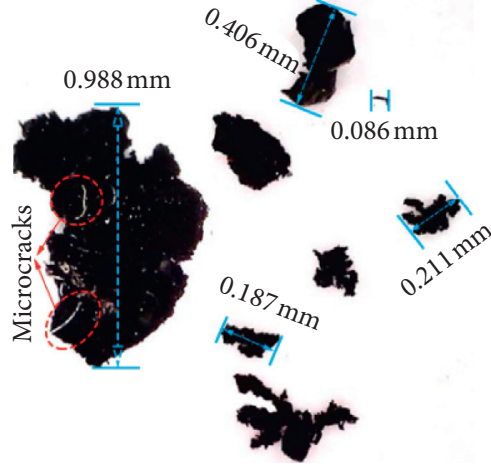

(c)

FIgURE 1: Tire rubber powder with different magnification (modified from [8]). (a) No magnification. (b) 50x magnification. (c) 100x magnification.

other parameters that affect the soil-structure interaction problem, including primary soil nonlinearities in the vicinity of the foundation [50]. For shallow foundation support, adding $10-15 \%$ rubber debris into the trench can improve the ultimate bearing capacity of the foundation and can even replace deep raft foundation and pavement base soil [51].

\subsubsection{Rubber Fiber Reinforced Soil. At present, there are few} studies on the use of rubber fiber in soil reinforcement. Previous studies have shown that the plasticity, toughness, and tensile crack resistance of clay can be improved by adding short fibers $[52,53]$. The authors of [54] studied the influence of rubber fiber content and soil gradation on soil properties and carried out a series of compaction tests and California bearing ratio tests (CBR). The results show that the optimal fiber content of cohesive soil and sandy soil is $1.5 \%$ and $1 \%$, respectively, and the incorporation of rubber fiber improves the ductility and energy absorption capacity of soil, especially for fine-grained cohesive soil. The authors of [55] added rubber fiber to cohesive soil and made unconfined compression test and splitting tensile test. The test results showed that, with the increase of rubber fiber content, the ultimate bearing capacity of cohesive soil decreases, but the plasticity and hardening properties improve. When the content of rubber fiber is $7.5 \%$, the absolute toughness and toughness index of the sample reaches maximum and the length of rubber fiber (about $1 \mathrm{~mm}$ ) used in this test are less than $0.5 \%$. The main research outcomes of the above two kinds of reinforcement with rubber fiber are summarized in Table 2.
2.2.3. Improvement of Soil with Rubber Powder and Rubber Particles. Rubber powder and rubber particles refer to nonstrip rubber with small particle size, which can reduce the density of the soil after mixing with the soil, so as to reduce the load on the foundation, but also can improve the shear strength of the soil and other mechanical properties [56]. At present, there are few studies on the influence of rubber particle size on rubber reinforced soil. Previous scholars generally address the application of rubber materials with coarse particle gradation, but it is difficult to combine these materials with soil when dealing with cohesive soil. Nevertheless, small-size materials such as rubber powder have better workability for fine-grained soil. This is because the rubber particles with small particle size are mostly powder or spherical, which are prone to dislocation and slip, while the particles with large particle size are mostly fragmented, which can better occlude and achieve better shear effect. The increase of shear strength of rubber reinforced soil is mainly caused by the increase of cohesion. The addition of rubber powder has no effect on the internal friction angle $[39,57]$. There are also studies on the influence of rubber particle size on the expansion, contraction, and consolidation properties of expansive soil. The mixing effect of granular rubber (average particle size $4.75-1.18 \mathrm{~mm}$ ) is better than that of fine-grained rubber $(1.18-0.075 \mathrm{~mm})$. However, there is no significant difference in the effect of rubber particle size on the strength $[58,59]$.

In fact, the research on rubber reinforced sandy soil is more complete. The existing research on rubber sand (RSM) shows that the strength of rubber sand is lower than that of matrix sand and the internal friction angle decreases with the 
TABLE 2: Summary of reinforcing soil with rubber fiber.

\begin{tabular}{|c|c|c|c|c|}
\hline $\begin{array}{l}\text { Reinforcement } \\
\text { method }\end{array}$ & Test name & Optimum content $(\%)$ & $\begin{array}{l}\text { Fiber length } \\
(\mathrm{mm})\end{array}$ & Reference \\
\hline \multirow{2}{*}{ Rubber fiber } & Compaction and CBR tests & $\begin{array}{c}\text { 1.5/1 (clayey soil/sandy } \\
\text { soil) }\end{array}$ & $10 \sim 30$ & {$[54]$} \\
\hline & $\begin{array}{l}\text { Unconfined compression test and splitting tensile } \\
\text { test }\end{array}$ & 7.5 & 1 & {$[55]$} \\
\hline
\end{tabular}

increase of rubber content $[36,60,61]$. Geogrid can be used as an effective method to improve the strength of rubber sand; research on geogrid is also one of the hot topics of many scholars [62-64]. The authors of [13] concluded that mortar containing 5\% rubber particles is suitable for flexible pavement, building facade, water purification system, and other civil applications (Table 3).

Current researches demonstrate that the soil reinforced by rubber can be divided into four categories: sandy soil, loess, expansive soil, and clay. The best mixing ratio of rubber is between $5 \%$ and $40 \%$. Relevant reinforcement methods in different soils are summarized in Table 4.

\section{Characteristics of Rubber Reinforced}

\subsection{Rubber Modified Sand}

\subsubsection{Physical Properties of Rubber Modified Sand.} Current researches on rubber sand mainly focus on the mechanical properties, but few focus on physical properties. The results show that the addition of rubber particles in sand can reduce the permeability and the minimum void ratio, but the maximum void ratio increases [71]. The density decreases with the increase of rubber particle content, and the bulk density of rubber sand is low and the durability is good [72]. In addition, according to one-dimensional compression test, adding a small amount of rubber particles can effectively reduce the volume density, the compressive deformation, and residual strain of small rubber sand, and the difference of residual strain decreases with the increase of sand content [73].

The authors of [74] carried out relevant tests on Poisson's ratio of rubber sand and found that when the rubber content is low $(\leq 10 \%)$, Poisson's ratio change pattern is similar to that of pure sand; when the rubber content is high ( $\geq 40 \%$ ), it is similar to that of pure rubber particles; when the rubber content is intermediate $(10 \%-35 \%)$, Poisson's ratio first increases with axial strain and then remains unchanged, and the change pattern is shown in Table 5. At the same time, according to Poisson's effect of rubber sand, the author puts forward the empirical estimation formula, which provides relevant reference for the follow-up researches.

\subsubsection{Mechanical Properties of Rubber Modified Sand. At} present, the research on the mechanical properties of rubber sand is mainly focused on the shear strength of sand, but whether the addition of rubber increases the shear strength of sand is still controversial. Some scholars believe that the shear strength of sand increases with the increase of rubber content, because the addition of rubber debris increases the internal friction angle of sand [49, 75, 76]; however, some scholars believe that the shear strength of sand will be reduced by adding rubber, because rubber particles will separate sand particles, resulting in interlocking and friction reduction between particles [38, 77]. The reason for the dispute may be due to the size of the rubber added. It has been proved that, under the condition of $10 \%$ rubber content, the shear strength of sand can be significantly improved by mixing waste tire rubber particles of $2-4 \mathrm{~mm}$ in diameter with sand; the internal friction angle of sand can be increased by mixing waste tire rubber particles of $0.5-2 \mathrm{~mm}$ in diameter with sand; however, when the waste tire rubber particles with particle size less than $0.5 \mathrm{~mm}$ are added, the internal friction angle of sand increases with the increase of the content that gradually decreases [78]. From the shear strength and deformation characteristics, it is concluded that the content of rubber particles plays a leading role when it exceeds $20 \%$. Some studies have shown that the rubber content to obtain the maximum shear strength is about $35 \%$, while the size of rubber fragments is not critical to the performance of sand $[3,36,49]$. In addition, the value of shear strength is also related to the water content and pore water pressure of the sand. The internal friction angle of rubber sand increases with the increase of water content, while the effect of pore water pressure on rubber sand is larger and the mechanism is more complex, which is worthy of further study. Some tests showed that the internal friction angle of saturated samples increases with the increase of rubber particles, while the internal friction angle of dry samples decreases with the content of rubber particles $[79,80]$.

In addition to the shear strength, there are many studies on the dynamic properties of rubber sand. The main tests used include dynamic triaxial test, resonant column test, and cyclic simple shear test. By summarizing the test results, the following conclusions can be drawn: the dynamic shear modulus of rubber sand decreases with the increase of rubber content, the dynamic elastic modulus decreases with the increase of tire particle content, the equivalent damping ratio increases first and then decreases with the rubber particle content, and the dynamic characteristics of rubber sand are greatly affected by water content, and the influence of particle size can be ignored [81-83]. In this regard, rubber sand with $20 \%$ rubber particle content can be selected in engineering projects [84]. However, the liquefaction resistance of rubber sand increases with the increase of rubber particle size and mixing amount. The addition of rubber particles with large particle size can significantly improve the liquefaction resistance of samples $[85,86]$. The authors of [87] studied the dynamic strength characteristics and pore 
TABLE 3: Summary of reinforcing soil with rubber powder/rubber particles.

\begin{tabular}{lccc}
\hline Reinforcement method & Optimum content $(\%)$ & Optimum particle size $(\mathrm{mm})$ & Reference \\
\hline & $10-20$ & $4.75-1.18$ & {$[59]$} \\
Rubber powder/particle & 50 & $4.5-0.075$ & {$[57]$} \\
& 20 & $5.00-0.50$ & {$[64]$} \\
\hline
\end{tabular}

TABLE 4: Application of various reinforcement methods in different types of soil.

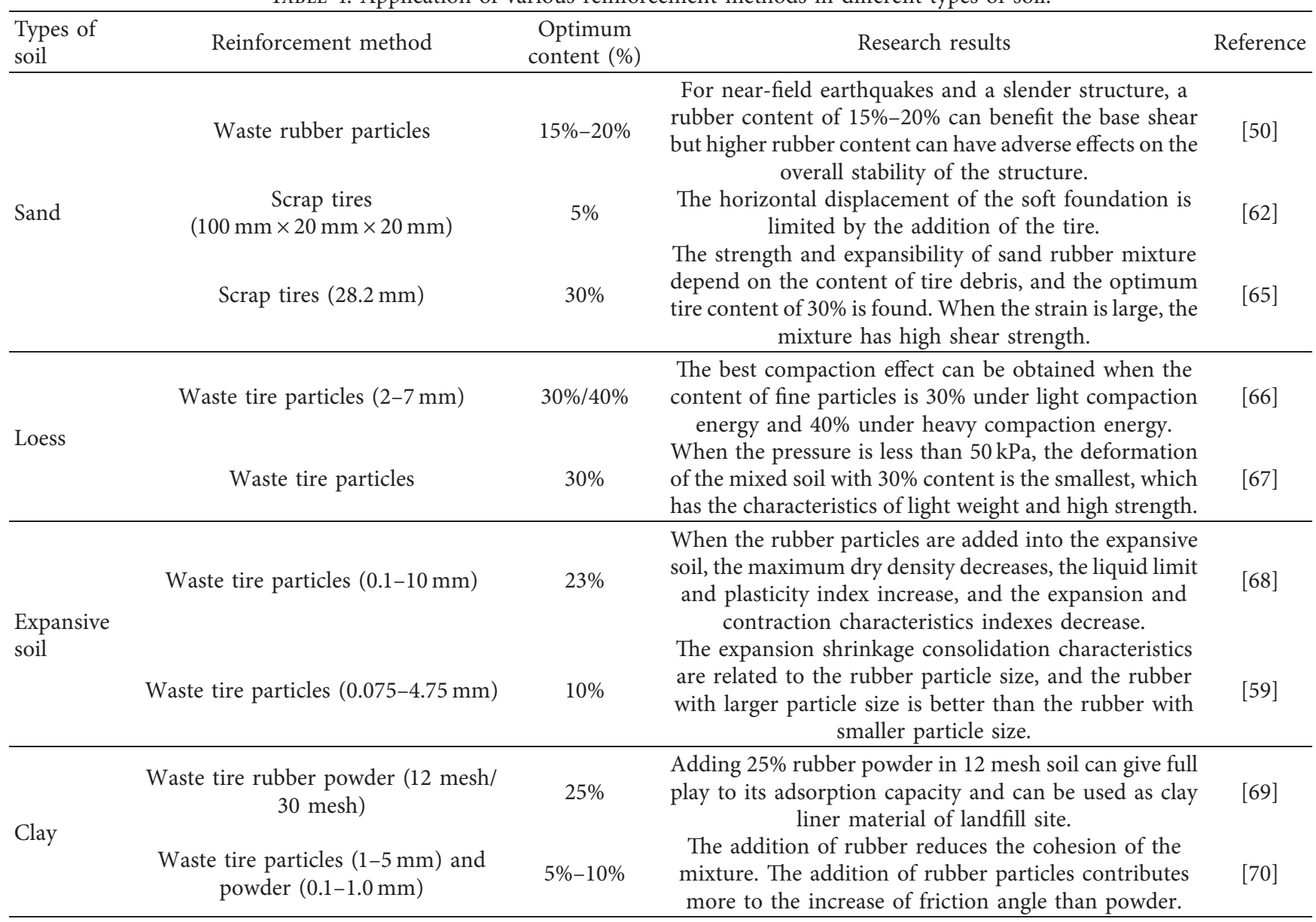

TABLE 5: Change rule of Poisson's ratio of rubber sand.

\begin{tabular}{lcc}
\hline Rubber content (\%) & Variation law of Poisson's ratio & Reference \\
\hline$\leq 10$ & Similar to pure sand \\
$10 \sim 35$ & With the increase of axial strain, it tends to be constant \\
$\geq 40$ & Similar to rubber particles \\
\hline
\end{tabular}

pressure development characteristics of rubber sand with rubber content through indoor dynamic triaxial test. The test results show that the liquefaction resistance of rubber sand increases with the increase of rubber content. The contact state of particles in rubber sand is shown in Figure 2.

The deformation mechanism of rubber sand can be seen as the interparticle dislocation of sand particles, which is restrained by rubber particles with good deformation ability, so that the original sand particle skeleton can be supported and stressed more effectively; from the perspective of force deformation relationship, 30\% 40\% rubber particle content is the best proportion of rubber sand [88].
3.2. Rubber Modified Clay. Clay is widely distributed in China, which has high moisture content, low shear strength, and bearing capacity, and is prone to uneven settlement. It is found that the mixing of granular or fragmented rubber into cohesive soil can reduce the mass of soil and improve the shear strength of soil mass $[89,90]$. Because the density of rubber particles is smaller than that of clay particles, the density of the mixture decreases [70]. Compared with cohesive plain soil, the dry bulk density and optimum water content of clay mixed with rubber particles are reduced, so the reinforced soil has lower specific gravity, which can be used as light filler [91, 92]. Rubber particles are larger than 


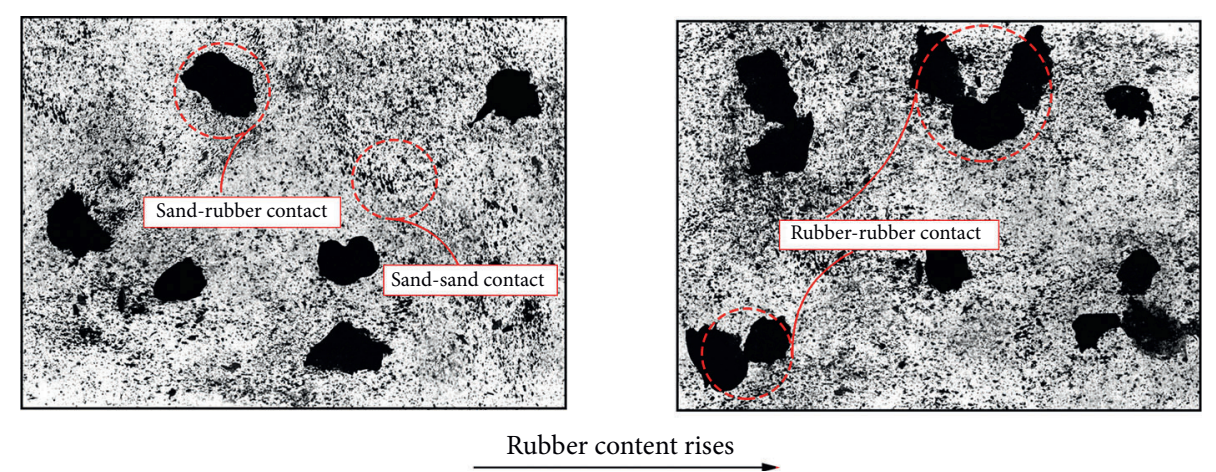

Figure 2: Contact state of particles in rubber sand (modified from [87]).

clay, which can also improve the permeability coefficient of soil and improve the drainage characteristics of clay [93]. Some studies have shown that rubber can reduce the dynamic shear modulus of clay and increase the damping ratio, which indicates that rubber can effectively improve the seismic isolation and shock absorption performance of clay $[32,94]$.

At present, there are few studies on the use of rubber to improve unsaturated clay, and the relevant results are not enough to support engineering practice. For cohesive soil, the incorporation of rubber particles can effectively improve its shear strength, and the addition of rubber powder will not have adverse effect on the internal strength of compacted clay [95]. It is found that the cohesion first increases and then decreases with the rubber content, while the internal friction angle gradually increases with the rubber content. During the shear process, the sample shows the characteristics of first shear shrinkage and then shear expansion [96]. In addition, some scholars hold different views. The authors of [97] studied unsaturated clay with different rubber powder mixing ratio and obtained the optimal mixing ratio of $2 \%$ and $4 \%$. In this test, the content of $2 \%$ and $4 \%$ can effectively improve the shear strength of soil, while the effective cohesion decreases under other mixing amounts, which is mainly due to the decrease of density of rubber soil, and the effect of microforce between grains is weakened. However, there is no unified understanding of the optimum rubber content for improving unsaturated clay. At present, a variety of test methods have been used to study the physical and mechanical properties of rubber clay. Table 6 summarizes the various experimental studies on rubber reinforcement of clay, the effect, and the optimum amount of rubber.

3.3. Rubber Modified Loess. Loess is mainly composed of silt with a certain proportion of fine sand, ultra-fine sand, and clay. The main clay minerals in loess are hydromica, kaolinite, and montmorillonite. Due to these minerals, the loess has good properties of adsorption, expansion, and contraction. Carbonate minerals often play the role of cementation, so that loess particles often exist as aggregates in the natural structure [98].

After encountering water, the collapsibility of loess is enhanced due to the destruction of soluble salt cemented aggregates. At present, there are a few studies on rubber reinforced loess, mainly focusing on its shear performance, compression performance, compaction performance, and dynamic characteristics, but the study of each performance is rare. Improvements of loess performance by rubber are summarized as follows:

(a) The shear characteristics of reinforced loess are mainly studied by using unconsolidated undrained triaxial test [99] and large-scale direct shear tests $[20,100]$ were carried out to study the shear properties of the composites, and the results showed that the shear strength increased with the increase of rubber content in a certain range. It is found that the shear strength of reinforced soil with $30 \% \sim 40 \%$ rubber content is significantly improved. When the content is lower than $20 \%$, the shear strength of the mixture is similar to that of plain compacted loess; when it is higher than $40 \%$, the shear strength of reinforced soil tends to that of pure rubber particles, and the shear strength is closely related to the length width ratio of rubber. Figure 3 [101] shows the change of shear strength with normal stress.

(b) The compression performance of rubber reinforced loess was tested by one-dimensional compression test. The test results show that the compression performance of the mixture is between pure compacted loess and pure granular rubber and the compression coefficient, elastic strain, and recovery strain increase with the increase of rubber content [102].

(c) By standard compaction test, it is found that the maximum dry density of the mixture decreases with the increase of the rubber content and the best compacted rubber content is $30 \% \sim 40 \%[66,103]$.

(d) By dynamic triaxial test, it is found that the maximum damping ratio of mixed soil increases with the increase of rubber content, while the dynamic modulus of elasticity decreases with the increase of rubber content [104].

\subsection{Properties of Rubber Modified Expansive Soil}

3.4.1. Physical Properties of Rubber Modified Expansive Soil. Expansive soil is a kind of high plastic clay mainly composed of montmorillonite, illite, and other hydrophilic clay 
TABLE 6: Reinforcing effect of rubber on clay.

\begin{tabular}{|c|c|c|c|}
\hline Test name & $\begin{array}{l}\text { Optimum } \\
\text { dosage (\%) }\end{array}$ & Effect & Reference \\
\hline $\begin{array}{l}\text { Indoor one-dimensional } \\
\text { consolidation test }\end{array}$ & 30 & $\begin{array}{l}\text { The consolidation rate of clay can be increased by } 400 \% \text { by adding tire rubber } \\
\text { particles }\end{array}$ & {$[90]$} \\
\hline Dynamic triaxial test & 6 & $\begin{array}{l}\text { The addition of rubber significantly reduces the dynamic shear modulus of } \\
\text { clay, increases its damping ratio, and improves its seismic performance }\end{array}$ & [94] \\
\hline California bearing ratio test & 10 & $\begin{array}{c}\text { Rubber can greatly improve the permeability and bearing capacity of clay and } \\
\text { reduce the thickness of pavement }\end{array}$ & {$[93]$} \\
\hline $\begin{array}{l}\text { Unconfined compression } \\
\text { test }\end{array}$ & 2 & $\begin{array}{l}\text { The results show that the damping ratio, shear modulus, and UCS value of the } \\
\text { sample are increased by adding } 2 \% \text { rubber fiber with the length of } 10 \mathrm{~mm}\end{array}$ & {$[32]$} \\
\hline
\end{tabular}

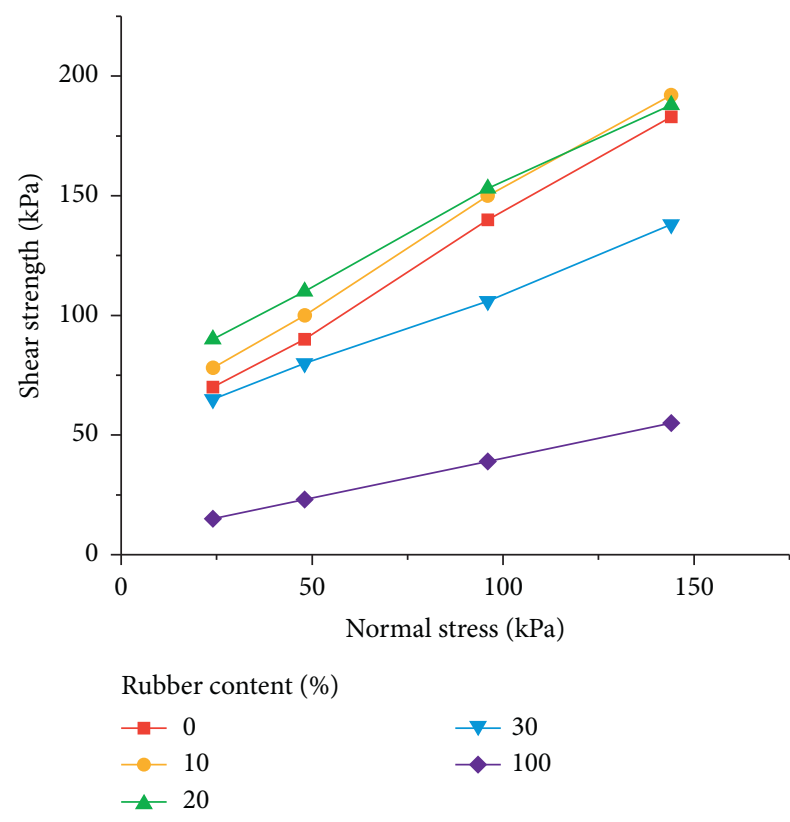

FIGURE 3: Shear strength of the mixture of tire strips and loess under different tire strip content (modified from [101]).

minerals [105]. It has adverse engineering properties such as swelling and shrinkage and attenuation of water immersion bearing capacity. It is extremely unstable. If untreated, it may cause engineering accidents. In recent years, many scholars have made a series of explorations to improve its properties [106]. Compared to the plain expansive soil, the liquid limit and plasticity index of the rubber modified expansive soil increase, the plastic limit changes slightly, and the maximum dry density decreases, but the optimal moisture content remains the same $[68,107]$. This may be because the density of rubber particles is small, which decreases the density of rubber expansive soil. However, the addition of rubber will reduce the stiffness of expansive soil, and Poisson's ratio will slightly increase with the increase of rubber content [108]. Some research results on the physical properties of expanded rubber soils are shown in Table 7.

3.4.2. Mechanical Properties of Rubber Modified Expansive Soil. The mechanical properties of ESR are well studied, including expansion characteristics, strength characteristics, and unconfined compressive strength. (a) Expansion and contraction characteristics

The analysis of mechanical properties of expansive soil is mainly obtained through the study of expansion force and expansion potential, so the expansion and contraction characteristics of expansive soil are also included in the mechanical characteristics for analysis. The addition of rubber particles can significantly reduce the swelling pressure, compression index, and expansion index of expansive soil $[59,112]$. This is due to the change of the composition of expansive soil after mixing with rubber particles. The content of hydrophilic minerals in the expansive soil decreases, and the rubber particles hinder the contact between soil particles and water, which reduces the expansibility and makes it easier to lose water, thus reducing the shrinkage limit and reducing the shrinkage deformation. Therefore, the improvement effect of rubber particles on expansive soil is very significant $[68,109]$.

Greatly affected by water, the swelling potential of expansive soil is closely related to the initial water content. The swelling potential of unsaturated soil depends on the distance from the fully saturated state. For the same material, the denser and drier the sample is, or the lower the initial moisture content is, the greater the swelling potential is [113]. At present, the main test methods for swelling shrinkage consolidation characteristics of expansive soil include one-dimensional consolidation test $[114,115]$, compaction test [59], and unloaded expansion rate and shrinkage tests [68]. Due to the expansion resistance provided by the contact between rubber and soil particles, the incorporation of rubber can reduce the expansion, contraction, and consolidation characteristics of expansive soil.

(b) Strength characteristics

The shear strength of the modified expansive soil depends on the internal friction angle and cohesion of the soil. At present, there is no unified understanding on whether rubber particles can increase the shear strength of expansive soil. Some scholars have found that the cohesion of rubber modified expansive soil decreases with the increase of the content of rubber, but the shear strength and internal 
TABLE 7: Characteristics of rubber reinforced expansive soil.

\begin{tabular}{|c|c|c|c|c|}
\hline Characteristic & $\begin{array}{l}\text { Optimum } \\
\text { rubber content } \\
\quad(\%)\end{array}$ & Test method & Conclusion & Reference \\
\hline $\begin{array}{l}\text { Physical } \\
\text { characteristics }\end{array}$ & 23 & Compaction test, etc. & $\begin{array}{l}\text { When the optimal moisture content remains } \\
\text { unchanged, the maximum dry density decreases, } \\
\text { and the liquid limit and plasticity index increase }\end{array}$ & {$[68]$} \\
\hline \multirow{2}{*}{$\begin{array}{l}\text { Expansion and } \\
\text { contraction } \\
\text { characteristics }\end{array}$} & $20 / 15$ & $\begin{array}{l}\text { Load expansion, expansion } \\
\text { force, and shrinkage test }\end{array}$ & $\begin{array}{l}\text { The swelling index of expansive soil decreases with } \\
\text { the increase of rubber powder }\end{array}$ & {$[59]$} \\
\hline & 20 & $\begin{array}{l}\text { Expansion consolidation and } \\
\text { loading and unloading tests, } \\
\text { etc. }\end{array}$ & $\begin{array}{l}\text { With the increase of rubber content, the liquid limit, } \\
\text { expansion potential, expansion pressure, and } \\
\text { maximum expansion time of soil gradually decrease }\end{array}$ & {$[109]$} \\
\hline \multirow{2}{*}{$\begin{array}{l}\text { Strength } \\
\text { characteristics }\end{array}$} & 20 & Unconfined compression test & $\begin{array}{c}\text { With the increase of rubber content, the increasing } \\
\text { trend of unconfined compressive strength gradually } \\
\text { disappears, and the strength reaches the maximum } \\
\text { when it reaches } 20 \%\end{array}$ & {$[110]$} \\
\hline & 8 & Triaxial shear test, etc. & $\begin{array}{l}\text { The cohesion decreases with the increase of rubber } \\
\text { content, and the friction angle increases with the } \\
\text { increase of rubber content }\end{array}$ & {$[111]$} \\
\hline
\end{tabular}

friction angle change little, and the overall shear strength decreases [68]. However, other scholars have concluded that the internal friction angle is not related to the rubber content, but the cohesion increases and the overall shear strength increases $[39,116]$, and the friction angle increases with the increase of rubber content [111]. Therefore, the shear properties of rubber expansive soil need to be further explored.

(c) Other mechanical properties

As for the mechanical properties of rubber expansive soil, there are more researches on its unconfined compressive strength. Through the unconfined compressive strength test, the influence of rubber content, moisture content, and other factors on its unconfined compressive strength is summarized. It is found that the unconfined compressive strength decreases with the increase of water content, increases with the increase of rubber content, and reaches the maximum at $20 \%$ and then has a downward trend [110]. In addition, due to the wide distribution of frozen soil in China, the influence of freeze-thaw cycle on expansive soil is particularly significant. Researchers have studied the characteristics of expansive soil under freeze-thaw cycle and used various methods to improve it. Among them, under the condition of freeze-thaw cycle, it is found that adding a certain amount of rubber particles can reduce the expansion and contraction effect of expansive soil. Nevertheless, when the content is too high, the expansion and contraction effect of expansive soil can be reduced. The change of volume of rubber expansive soil is more affected by freeze-thaw cycles than that of plain expansive soil [117].

To sum up, the researchers conducted a series of tests on the physical and mechanical properties of rubber expansive soil. It was found that the addition of rubber improves the soil mechanical properties of expansive soil. It was concluded that the optimal mixing amount of rubber is between $8 \%$ and $23 \%$. Some research results are shown in Table 7 . It is urgent to improve the expansive soil, but the relevant research in the field of rubber reinforced soil is not perfect, which is an urgent problem to be solved. At present, researchers still need to explore new methods to improve the strength of expansive soil and to reduce its expansion and shrinkage.

\section{Application of Rubber Reinforced Soil in Civil Engineering}

4.1. Rubber Reinforced Soil Used as Isolation and Damping Material. In recent years, the use of base isolation system and energy dissipation materials has been proved to be an effective means of structural seismic resistance. The traditional isolation system usually achieves the seismic requirements by increasing the structural strength and ductility, while the new isolation and damping system focuses more on changing the structural stiffness and damping ratio to reduce the seismic wave intensity reaching the upper part of the structure [118].

Due to its light weight and large damping energy, rubber is often used to reduce earthquake force and absorb earthquake vibration [26]. When rubber reinforced soil is placed around the building foundation, it is equivalent to an isolation cushion. The structural response can be reduced by $40-60 \%$ in terms of acceleration and interlayer displacement $[10,119]$. Compared with pure sand, rubber sand has higher damping ratio and better damping characteristics, which has positive significance for earthquake resistance, and the damping ratio of dry sand is higher than that of saturated sand $[27,120]$. For medium- and high-rise buildings, rubber sand can replace pure sand as foundation layer, which can reduce foundation shear and maximum interlayer displacement to $40 \%$ and $30 \%$, respectively [121]. 
At present, the cyclic triaxial test to test the seismic performance of rubber reinforced soil has become a research hotspot. The test results show that the rubber with $10 \%$ sand and $6 \%$ clay has good seismic isolation and shock absorption performance $[94,120]$. The number of cycles also has an impact on its seismic performance. It is found that, under small vertical stress, with the increase of the number of cycles, the energy absorption and damping effect of rubber sand decrease, while, under large vertical stress, the influence of cycle times is not significant [88].

The authors of [10] proposed an isolation method suitable for developing countries, which is similar to the traditional structure seismic isolation system using laminated rubber bearings and spherical sliding bearings. The comparison can be made as shown in Figure 4. The vertical vibration level is significantly reduced by using rubber soil and cushion (RSM). The authors also developed a finite element program to model the dynamic response of soil-base-structure system to evaluate the effectiveness of the proposed method. The possibly low cost of these infrastructure protection methods can greatly benefit impoverished countries where resources and technology are inadequate for hazard mitigation using welldeveloped, yet expensive, techniques $[122,123]$ that conducted a series of large-scale underwater shaking table tests on gravity caissons. The compressibility and energy absorption capacity of the cushion layer made of tire debris were used to reduce the load of the retaining structure. The test results show that the method can significantly reduce the seismic load and residual displacement of caisson bank wall. However, some researchers believe that the rubber reinforced soil as a seismic isolation method will reduce the soil stiffness and made stiffness reduce, which needs to be explored and improved by more researchers.

4.2. Rubber Reinforced Soil Used as Light Backfill Material. As a backfill material, rubber reinforced soil has the advantages of light weight, good water permeability, and good deformation ability, which is conducive to improving the deformation and drainage capacity of soil and reducing the inertial force during earthquake. It can be used as new backfill material and coastal coating material behind embankment and retaining wall $[49,57,99,124,125]$. Through numerical analysis, it is found that the internal friction angle has a great influence on the displacement, so the filling materials with larger internal friction angle such as sand are selected as far as possible in the construction of retaining wall $[43,126]$. Compared with pure sand, rubber sand, as a lightweight backfill material, can reduce the horizontal displacement and earth pressure of retaining wall to $50 \%$ $60 \%$. The deformation of geotextile filled with rubber particles is usually hardening. With the increase of rubber content, the shear stress of the geotextile decreases [44, 127-129]. Some researchers have compared the interaction coefficient of rubber sand mixture and pure sand backfill. The research shows that the rubber sand mixture with 30:70 weight ratio has the highest tensile strength and shear strength, which is due to its highest shear strength and highest dry density [130].
At present, in addition to the use of rubber sand as retaining wall and backfill material, the research hotspot is also the performance of rubber expansive soil mixed as subgrade [131-133]. The test results show that the incorporation of tire particles effectively increases the shear and compressive properties of soil and each performance is positively related to the curing age. However, rubber clay is better not to be used when drainage is needed to prevent the development of pore pressure during the filling sandwich under saturated conditions [31], and when rubber reinforced soil improves foundation eccentricity and foundation bearing capacity [51, 134, 135], it is not suggested to be applied. The authors of [136] studied the simulation of seawall reinforced by waste tire debris. Through comparative analysis, it was concluded that the stress-strain relationship of seawall reinforced with rubber is significantly reduced compared with that of unreinforced seawall, which was a feasible method.

To sum up, rubber reinforced soil as a lightweight backfill material can be used for backfill of retaining wall, improvement of foundation settlement, embankment filling and seafloor reinforcement, etc., as shown in Table 8.

4.3. Rubber Reinforced Soil Used as Landfill Liner. Adding rubber particles into the clay liner can reduce the density. When the rubber content is large, the pad adsorption capacity increases. However, in order to reduce the permeability of the liner, the amount of rubber should be controlled within a certain range [137]. Comprehensive consideration of various properties, it is concluded that the optimal dosage of rubber powder modified clay with 12 mesh and 25\% rubber powder can be used as landfill clay liner material [69].

The authors of [138] added tire debris into sand bentonite mixture. Through consolidation test, it was proved that rubber debris can significantly improve the shear strength and hydraulic conductivity of the mixture. $10 \%$ of rubber debris can be used as landfill liner, and 15\% of tire debris can be used for landfill cover. The surface structure of rubber fragments before and after shearing is magnified by 500 times by electron microscope, as shown in Figure 5 . Obvious microcracks appear on the surface wall of rubber after shearing, which is closely related to the tensile force of rubber fragments. Some data show that the use of rubber debris to suppress dry cracks in the clay lining of landfills can be reduced by $40 \% \sim 80 \%$ [139].

The addition of rubber increases the effective cohesion and effective internal friction angle of sand bentonite mixture. In addition, increasing the content of rubber debris can also improve the hydraulic conductivity and consolidation coefficient of rubber reinforced soil, which are important factors affecting landfill liner materials [140].

\section{Current Problems and Prospects}

As a new technology of soil reinforcement, rubber reinforced soil needs to be further explored by researchers, and the main research problems are as follows: 


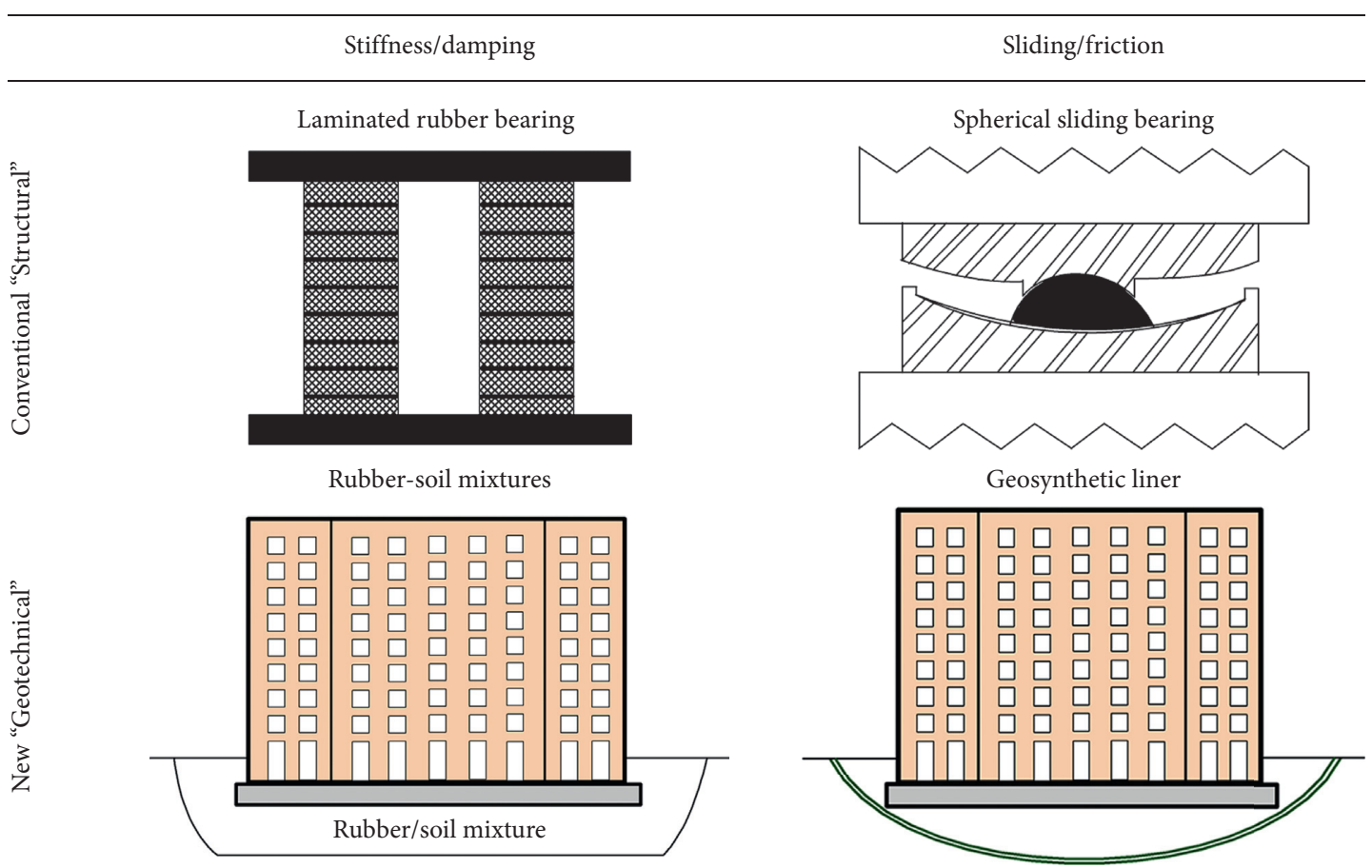

Figure 4: Recommended isolation system classification (modified from [10]).

TABLE 8: Application of rubber reinforced soil as backfill.

\begin{tabular}{|c|c|c|c|}
\hline Application & Types of soil & Characteristic & Reference \\
\hline $\begin{array}{l}\text { Backfill of retaining } \\
\text { wall }\end{array}$ & Sand & $\begin{array}{l}\text { The retaining wall is made of hollow rectangular steel, and the mixture of different } \\
\text { particle sizes is used as backfill material. The horizontal displacement and horizontal } \\
\text { earth pressure can be reduced to } 50-60 \% \text { of the horizontal displacement and horizontal } \\
\text { earth pressure of the control box. }\end{array}$ & {$[44]$} \\
\hline $\begin{array}{l}\text { Improving the } \\
\text { foundation }\end{array}$ & Sand & $\begin{array}{l}\text { The addition of waste rubber particles significantly improves the load settlement } \\
\text { characteristics of eccentric load footings. The recommended maximum tire debris } \\
\text { content is } 30 \% \text {. }\end{array}$ & [135] \\
\hline Subgrade filling & $\begin{array}{l}\text { Expansive } \\
\text { soil }\end{array}$ & $\begin{array}{l}\text { From economical perspective, the best content of rubber particles should not exceed } \\
\qquad 15 \%\end{array}$ & {$[132]$} \\
\hline $\begin{array}{l}\text { Seawall } \\
\text { reinforcement }\end{array}$ & Silty clay & $\begin{array}{l}\text { The horizontal displacement of the embankment is greatly reduced, and the horizontal } \\
\text { stress of the embankment is greatly reduced. }\end{array}$ & [136] \\
\hline
\end{tabular}

(1) For rubber reinforced soil, compaction is an important step in production and placement. In this case, the maximum dry density decreases with the increase of rubber content, which is inconsistent with the trend of optimum moisture content studied. With the gradual maturity of rubber reinforced soil system, it is necessary to use a simple and effective method to fully predict its compaction performance to facilitate the designing of reliable rubber reinforced soil without laboratory compaction test.

(2) In terms of reinforcement methods, rubber content is the main source of soil improvement, but the geometric properties of rubber also play an important role. However, most of the tests are aimed at studying the influence of rubber content on soil, and the research on the influence of rubber size on soil has not formed a consensus.
(3) From the perspective of soil types, scholars have relatively completed research on the shear strength and dynamic characteristics of sand mixed with rubber, and there are also relevant engineering applications; however, for other types of soil, such as expansive soil, which has adverse effects on the project,. studies are insufficient

(4) For soil properties, there is a lack of in-depth study of soil physical properties. The mechanical properties of soil, such as shear strength, have been studied by predecessors. The physical properties and how to balance the relationship between strength and other properties in practical engineering application are also worth discussing, because the strength of rubber particles is not high in most cases compared with soil particles. 


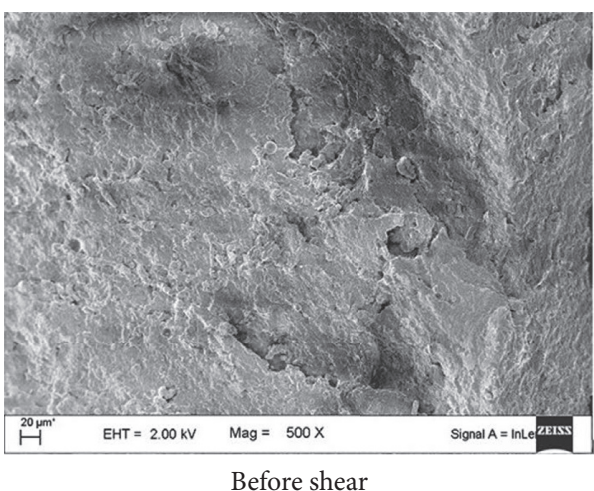

(a)

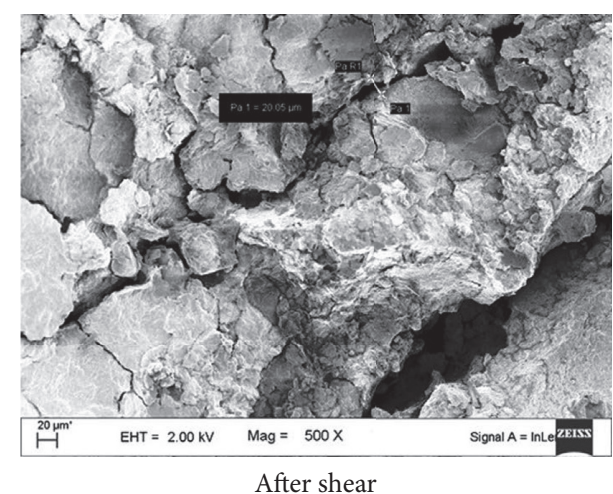

(b)

Figure 5: Surface before and after shearing of rubber fragments (modified from [138]). (a) Before shear and (b) after shear.

(5) Whether the rubber reinforced soil will have adverse effects on the environment in the long run has not been fully recognized in the literature.

To sum up, future research on rubber reinforced soil can focus on the influence of different sizes of rubber on soil properties, the physical properties of expansive soil such as expansion, contraction, and consolidation, and the durability of rubber soil. It is expected that scholars can actively explore and make a breakthrough in the research and application of rubber reinforced soil.

\section{Conclusion}

In this paper, the new progress of rubber reinforced soil technology in recent years is reviewed. The methods and effects of rubber reinforcement in different soils are introduced from the aspects of rubber types, reinforcement methods, and physical and mechanical properties. At the same time, this paper introduces the practical engineering application related to rubber reinforced soil, in order to understand the new development trend of rubber reinforced soil technology and explore the research direction. The incorporation of rubber can improve the shear strength, unconfined compression strength, and compression consolidation characteristics. The main research results are as follows:

(1) The results show that the bearing capacity and shear strength of the soil treated with rubber reinforcement are improved in varying degrees. For sand, the addition of rubber with good elasticity can restrain the interparticle dislocation of sand particles, obtain a certain cohesion, and effectively improve the physical and mechanical properties of sand.

(2) Rubber reinforcement can effectively improve the deformation characteristics of cohesive soil. For expanded rubber soil, rubber can surround the soil particles and reduce the expansion and contraction characteristics of expansive soil. When rubber powder particles with similar particle size are added into the soil, an interconnected network structure is formed to increase the cohesion. (3) The amount of rubber is an important factor affecting the rubber reinforcement, but the influence of rubber size on the properties of rubber reinforced soil is not significant. Under different test conditions, there is an optimal content to take the advantages of rubber reinforcement.

(4) Rubber reinforced soil provides a new way for the recovery and reuse of waste tires. The density of tire rubber is small, and it can be used as light filler to reduce settlement after mixing with different soils. Also, rubber has large elasticity and good energy absorption capacity, which can be used in isolation cushion, landfill liner, embankment abutment, and other projects. However, considering that the components of tire derived products contain heavy metals, whether it will have adverse effects on the environment when reused or exposed to the air and whether the elasticity of rubber will fail need further research.

(5) Rubber reinforced soil, as a new type of geotechnical material, lacks a generally accepted standard.

\section{Data Availability}

The data used to support the findings of this study are available from the corresponding author upon request.

\section{Conflicts of Interest}

The authors declare that there are no conflicts of interest regarding the publication of this paper.

\section{Acknowledgments}

This work was supported by the Key R\&D Plans of Shandong Province (no. 2019GHY112075), the Special Project Fund of Taishan Scholars of Shandong Province, China (no. 2015212), and the National Major Scientific Research Instrument 
Development Project (no. 41627801), which are gratefully acknowledged.

\section{References}

[1] J. Dargay, G. Dermot, and S. Martin, "Vehicle ownership and income growth, worldwide: 1960-2030," The Energy Journal, vol. 28, no. 4, pp. 143-170, 2007.

[2] M. Saberian, J. Li, and S. Setunge, "Evaluation of permanent deformation of a new pavement base and subbase containing unbound granular materials, crumb rubber and crushed glass," Journal of Cleaner Production, vol. 230, no. 1, pp. 38-45, 2019.

[3] H. Pincus, T. Edil, and P. Bosscher, "Engineering properties of tire chips and soil mixtures," Geotechnical Testing Journal, vol. 17, no. 4, pp. 453-464, 1994.

[4] N. Oikonomou and S. Mavridou, "The use of waste tyre rubber in civil engineering works," in Book: Sustainability of Construction Materials, pp. 213-238, Elsevier, Amsterdam, Netherlands, 2009.

[5] R. K. Vieira, R. C. Soares, S. C. Pinheiro, O. A. Paiva, J. O. Eleutério, and R. P. Vasconcelos, "Completely random experimental design with mixture and process variables for optimization of rubberized concrete," Construction and Building Materials, vol. 24, no. 9, pp. 1754-1760, 2010.

[6] P. F. Torgal, Y. Ding, and S. Jalali, "Properties and durability of concrete containing polymeric wastes (tyre rubber and polyethylene terephthalate bottles): an overview," Construction and Building Materials, vol. 30, pp. 714-724, 2012.

[7] M. S. Mashiri, J. S. Vinod, M. N. Sheikh, and H.-H. Tsang, "Shear strength and dilatancy behaviour of sand-tyre chip mixtures," Soils and Foundations, vol. 55, no. 3, pp. 517-528, 2015.

[8] A. Soltani, A. Deng, A. Taheri, and M. Mirzababaei, "Rubber powder-polymer combined stabilization of south Australian expansive soils," Geosynthetics International, vol. 25, no. 3, pp. 304-321, 2018.

[9] P. J. Bosscher, T. B. Edil, and S. Kuraoka, "Design of highway embankments using tire chips," Journal of Geotechnical and Geoenvironmental Engineering, vol. 123, no. 4, pp. 295-304, 1997.

[10] H.-H. Tsang, S. H. Lo, X. Xu, and M. Neaz Sheikh, "Seismic isolation for low-to-medium-rise buildings using granulated rubber-soil mixtures: numerical study," Earthquake Engineering \& Structural Dynamics, vol. 41, no. 14, pp. 20092024, 2012.

[11] Y. Liu, Study on Mechanical Properties of Waste Tire Strips and Bearing Characteristics and Deformation of Reinforced Embankment Slopes, Shandong University, Jinan, China, 2019.

[12] M. N. Sheikh, S. Mashiri, J. S. Vinod et al., "“Shear and compressibility behavior of sand-tire crumb mixtures," Journal of Materials in Civil Engineering, vol. 25, no. 10, pp. 1366-1374, 2013.

[13] A. F. Angelin, M. F. F. Andrade, R. Bonatti, R. C. Cecche Lintz, L. A. Gachet-Barbosa, and W. R. Osório, "Effects of spheroid and fiber-like waste-tire rubbers on interrelation of strength-to-porosity in rubberized cement and mortars," Construction and Building Materials, vol. 95, pp. 525-536, 2015.

[14] L. H. Li and C. D. Yu, "Properties of soil reinforced by waste tire," Journal of Yangtze River Scientific Research Institute, vol. 36, no. 11, pp. 1-6, 2019.
[15] L. H. Li, H. L. Xiao, J. J. Zheng et al., "The model slope of waste tire reinforced slope," Engineering Mechanics, vol. 32, no. 11, pp. 79-85, 2015.

[16] M. Saberian, J. Li, B. T. Nguyen et al., "Estimating the resilient modulus of crushed recycled pavement materials containing crumb rubber using the clegg impact value," Resources Conservation and Recycling, vol. 141, pp. 301-307, 2018.

[17] E. J. Hoppe, "Field study of shredded-tire embankment," Transportation Research Record: Journal of the Transportation Research Board, vol. 1619, no. 1, pp. 47-54, 1998.

[18] M. A. Rahgozar and M. Saberian, "Geotechnical properties of peat soil stabilised with shredded waste tyre chips," Mires and Peat, vol. 18, no. 3, pp. 1-12, 2016.

[19] Q. Li, Experimental Research on Creep Properties of the Geosynthetics in the GRPS Embankment, Guilin University Of Electronic Technology, Guilin, China, 2019.

[20] J. W. Xu, Z. P. Hu, S. L. Ma et al., "Effect of barite powder and rubber powderon the shear strength of manipulated loess," Journal of Xi'an University Of Science And Technology, vol. 33, no. 5, pp. 565-570, 2013.

[21] A. AbdelRazek, R. M. El-Sherbiny, and H. A. Lotfi, "Mechanical properties and time-dependent behaviour of sandgranulated rubber mixtures," Geomechanics and Geoengineering, vol. 13, no. 4, pp. 288-300, 2018.

[22] A. Marto, N. Latifi, R. Moradi et al., "“Shear properties of sand-tire chips mixtures," Electronic Journal of Geotechnical Engineering, vol. 18, pp. 325-333, 2013.

[23] E. T. Mohamad, N. Latifi, A. Marto et al., "Effects of relative density on shear strength characteristics of sand-tire chips mixture," Electronic Journal of Geotechnical Engineering, vol. 18, pp. 623-632, 2013.

[24] S. M. Anvari, I. Shooshpasha, and S. S. Kutanaei, "Effect of granulated rubber on shear strength of fine-grained sand," Journal of Rock Mechanics and Geotechnical Engineering, vol. 9, no. 5, pp. 936-944, 2017.

[25] B. Li, M. Huang, and X. Zeng, "Dynamic behavior and liquefaction analysis of recycled-rubber sand mixtures," Journal of Materials in Civil Engineering, vol. 28, no. 11, Article ID 4016122, 2016.

[26] A. Nakhaei, S. M. Marandi, S. Sani Kermani, and M. H. Bagheripour, "Dynamic properties of granular soils mixed with granulated rubber," Soil Dynamics and Earthquake Engineering, vol. 43, pp. 124-132, 2012.

[27] M. Ehsani, N. Shariatmadari, and S. M. Mirhosseini, "Shear modulus and damping ratio of sand-granulated rubber mixtures," Journal of Central South University, vol. 22, no. 8, pp. 3159-3167, 2015.

[28] A. Brara, A. Brara, A. Daouadji, A. Bali, and E. Mostafa Daya, "Dynamic properties of dense sand-rubber mixtures with small particles size ratio," European Journal of Environmental and Civil Engineering, vol. 21, no. 9, pp. 1065-1079, 2016.

[29] G. A. Pistolas, A. Anastasiadis, and K. Pitilakis, "Dynamic behaviour of granular soil materials mixed with granulated rubber: effect of rubber content and granularity on the smallstrain shear modulus and damping ratio," Geotechnical and Geological Engineering, vol. 36, 2017.

[30] G. A. Pistolas, A. Anastasiadis, and K. Pitilakis, "Dynamic behaviour of granular soil materials mixed with granulated rubber: influence of rubber content and mean grain size ratio on shear modulus and damping ratio for a wide strain range," Innovative Infrastructure Solutions, vol. 3, no. 1, 2018.

[31] H. Cetin, M. Fener, and O. Gunaydin, "Geotechnical properties of tire-cohesive clayey soil mixtures as a fill 
material," Engineering Geology, vol. 88, no. 1, pp. 110-120, 2006.

[32] S. Akbulut, S. Arasan, and E. Kalkan, "Modification of clayey soils using scrap tire rubber and synthetic fibers," Applied Clay Science, vol. 38, no. 1, pp. 23-32, 2007.

[33] J. Dunham-Friel and J. A. H. Carraro, Effects of Compaction Effort, Inclusion Stiffness and Rubber Size on the Shear Strength and Stiffness of Expansive Soil-Rubber (ESR) Mixtures, Geotechnical Special Publication, Auburn, IN, USA, 2014.

[34] J. S. Yadav and S. K. Tiwari, "Evaluation of the strength characteristics of cement-stabilized clay-crumb rubber mixtures for its sustainable use in geotechnical applications," Environment, Development and Sustainability, vol. 20, no. 5, pp. 1961-1985, 2017.

[35] S. Ghareh, F. Akhlaghi, and K. Yazdani, "A study on the effects of waste rubber tire dimensions on fine grained soil behavior," Journal of Rehabilitation in Civil Engineering, vol. 8, no. 3, pp. 15-33, 2020.

[36] J. G. Zornberg, A. R. Cabral, and C. Viratjandr, "Behaviour of tire shred - sand mixtures," Canadian Geotechnical Journal, vol. 41, no. 2, pp. 227-241, 2004.

[37] M. Ghazavi, "Shear strength characteristics of sand-mixed with granular rubber," Geotechnical and Geological Engineering, vol. 22, pp. 401-416, 2004.

[38] R. El-Sherbiny, A. Y. A. Razek, and H. Lotfy, Triaxial Testing on Saturated Mixtures of Sand and Granulated Rubber, Geotechnical Special Publication, Auburn, IN, USA, 2013.

[39] S. L. Sun, Y. Y. Wei, and X. Zhang, "Research on shear strength of expansive soils reinforced with waste tire powders," Chinese Journal of Rock Mechanics and Engineering, vol. 28, no. 1, pp. 3070-3075, 2009.

[40] H.-K. Kim and J. C. Santamarina, "Sand-rubber mixtures (large rubber chips)," Canadian Geotechnical Journal, vol. 45, no. 10, pp. 1457-1466, 2008.

[41] P. S. H. Poh and B. B. Broms, "Slope stabilization using old rubber tires and geotextiles," Journal of Performance of Constructed Facilities, vol. 9, no. 1, pp. 76-79, 1995.

[42] J. J. Tweedie, D. N. Humphrey, and T. C. Sandford, "Tire shreds as lightweight retaining wall backfill: active conditions," Journal of Geotechnical and Geoenvironmental Engineering, vol. 124, no. 11, pp. 1061-1070, 1998.

[43] J. H. Lee, R. Salgado, A. Bernal, and C. W. Lovell, "Shredded tires and rubber-sand as lightweight backfill," Journal of Geotechnical and Geoenvironmental Engineering, vol. 125, no. 2, pp. 132-141, 1999.

[44] S. B. Reddy and A. M. Krishna, "Recycled tire chips mixed with sand as lightweight backfill material in retaining wall applications: an experimental investigation," International Journal of Geosynthetics and Ground Engineering, vol. 1, no. 4, 2015.

[45] H. H. Tsang, "“Seismic isolation by rubber-soil mixtures for developing countries," Earthquake Engineering \& Structural Dynamics, vol. 37, no. 2, pp. 823-303, 2008.

[46] F. C. Liu, M. T. Wu, and J. Yang, "Experimental study of strength characteristics of geogrid reinforced rubber sand mixtures," Rock and Soil Mechanics, vol. 40, no. 2, pp. 580-591, 2019.

[47] M. F. Attom, "The use of shredded waste tires to improve the geotechnical engineering properties of sands," Environmental Geology, vol. 49, no. 4, pp. 497-503, 2005.

[48] P. Anbazhagan, D. R. Manohar, and D. Rohit, "Influence of size of granulated rubber and tyre chips on the shear strength characteristics of sand-rubber mix," Geomechanics and Geoengineering, vol. 12, no. 4, pp. 266-278, 2016.

[49] L. H. Li, H. L. Xiao, H. M. Tang et al., "Shear performance optimizing of tire shred-sand mixture," Rock and Soil Mechanics, vol. 34, no. 4, pp. 1063-1067, 2013.

[50] G. A. Pistolas, K. Pitilakis, and A. Anastasiadis, "A numerical investigation on the seismic isolation potential of rubber/soil mixtures," Earthquake Engineering and Engineering Vibration, vol. 19, no. 3, pp. 683-704, 2020.

[51] G. S. Hambirao, Dr. P. G. Rakaraddi, and D. P. G. Rakaraddi, "Soil stabilization using waste shredded rubber tyre chips," IOSR Journal of Mechanical and Civil Engineering, vol. 11, no. 1, pp. 20-27, 2014.

[52] Z. H. O" zkull and G. Baykal, "Shear strength of clay with rubber fiber inclusions," Geosynthetics International, vol. 13, no. 5, pp. 173-180, 2006.

[53] M. Bekhiti, H. Trouzine, and M. Rabehi, "Influence of waste tire rubber fibers on swelling behavior, unconfined compressive strength and ductility of cement stabilized bentonite clay soil," Construction and Building Materials, vol. 208, pp. 304-313, 2019.

[54] M. Tafti and M. Z. Emadi, "Impact of using recycled tire fibers on the mechanical properties of clayey and sandy soils," Electronic Journal of Geotechnical Engineering, vol. 21, pp. 7113-7125, 2016.

[55] J. S. Yadav, S. Hussain, S. K. Tiwari, and A. Garg, "Assessment of the load-deformation behaviour of rubber fibrereinforced cemented clayey soil," Transportation Infrastructure Geotechnology, vol. 6, no. 2, pp. 105-136, 2019.

[56] L. Xin, H. L. Liu, Y. Shen et al., "Consolidated undrained triaxial compression tests on lightweight soil mixed with rubber chips of scrap tires," Chinese Journal of Geotechnical Engineering, vol. 32, no. 3, pp. 428-433, 2010.

[57] J. Zhou, "Study on dynamic characteristics of waste tyre rubber particle mixed soil," Hunan Communication Science And Technology, vol. 44, no. 3, pp. 65-69, 2018.

[58] Y. Duan, H. Jin, and Q. Zheng, "Testing study on moisture content effect on thermal conductivity for clay and sand," Yellow River, vol. 38, no. 2, pp. 117-120, 2016.

[59] A. Soltani, A. Deng, A. Taheri, and A. Sridharan, "Swellshrink-consolidation behavior of rubber-reinforced expansive soils," Geotechnical Testing Journal, vol. 42, no. 3, Article ID 20170313, 2019.

[60] A. F. Cabalar, "Direct shear tests on waste tires-sand mixtures," Geotechnical and Geological Engineering, vol. 29, no. 4, pp. 411-418, 2010.

[61] J. S. Vinod, N. Sheikh, and D. Mastello, "The direct shear strength of sand tyre shred mixtures," in Proceedings of the International Conference on Geotechnical Engineering, pp. 193-196, ICGE Colombo, Colombo, Sri Lanka, 2015.

[62] L. H. Li, Y. Liu, H. L. Xiao et al., "Tyre pieces of reinforced sand subgrade bearing capacity test," Highway Engineering, vol. 41, no. 3, pp. 64-68, 2016.

[63] Z. J. He, A. Siga, and J. F. Zou, "Research for reinforced finegrained sand based on large-scale triaxial tests," Journal of Railway Science and Engineening, vol. 16, no. 10, pp. 24512458, 2019.

[64] F. C. Liu, M. T. Wu, and L. P. Jing, "Experimental study on the isolating performance of a new reinforced rubber-sand mixture composite cushion," Journal of Vibration and Shock, vol. 38, no. 22, pp. 184-197, 2019.

[65] L. Balachowski and P. Gotteland, "Characteristics of tyre chips-sand mixtures from triaxial tests," Archives of 
Hydroengineering and Environmental Mechanics, vol. 54, no. 1, pp. 3-14, 2007.

[66] Z. H. Li and H. Y. Zhang, "Compaction properties of granulated rubber and loess mixtures," Rock and Soil Mechanics, vol. 31, no. 12, pp. 3715-3720, 2010.

[67] Z. H. Li and H. Y. Zhang, "The compressibility of granulated rubber and loess mixtures," Geotechnical Investigation \& Surveying, vol. 40, no. 3, pp. 12-17, 2012.

[68] W. L. Zou, P. Xie, Q. T. Ma et al., "Experiment on characteristics of expansive soil modified with waste tire rubber particles," Journal of Sichuan University, vol. 43, no. 3, pp. $44-48,2011$.

[69] J. He, X. Hu, Y. Li et al., "Effects of ground rubber on compressibility, shrinkageand hydraulic conductivity of kaolin soils," Journal of Engineering Geology, vol. 25, no. 1, pp. 65-72, 2017.

[70] M. Jastrzębska, "Strength characteristics of clay-rubber waste mixtures in uu triaxial tests," Geosciences, vol. 9, no. 8, p. 352, 2019.

[71] R. Chaney, K. Demars, Z.-Y. Feng, and K. Sutter, "Dynamic properties of granulated rubber/sand mixtures," Geotechnical Testing Journal, vol. 23, no. 3, pp. 338-344, 2000.

[72] E. Q. Zhou and Q. Wang, "Experimental investigation on shear strength and liquefaction potential of rubber-sand mixtures," Advances in Civil Engineering, vol. 2019, Article ID 5934961, 11 pages, 2019.

[73] T. Zhang, S. Y. Liu, and G. J. Cai, "Experimental on compression characteristics and bonding degradation of rubber sand mixtures," China Journal of Highway and Transport, vol. 31, no. 11, pp. 21-30, 2018.

[74] F. C. Liu, M. T. Wu, N. Liu et al., "Experimental study on poisson's ratio of rubber-sand mixtures," Chinese Journal of Rock Mechanics and Engineering, vol. 36, no. 1, pp. 35963606, 2017.

[75] P. Anbazhagan and D. R. Manohar, "Energy absorption capacity and shear strength characteristics of waste tire crumbs and sand mixtures," International Journal of Geotechnical Earthquake Engineering, vol. 6, no. 1, pp. 28-49, 2015.

[76] K. Daud, "Soil improvement using waste tire chips," International Journal of Civil Engineering and Technology, vol. 9, no. 8, pp. 1338-1345, 2018.

[77] C. Lee, H. Shin, and J.-S. Lee, "Behavior of sand-rubber particle mixtures: experimental observations and numerical simulations," International Journal for Numerical and Analytical Methods in Geomechanics, vol. 38, no. 16, pp. 16511663, 2014

[78] C. Dong, D. Y. Li, and S. S. Li, "Effects of scrap tire crumb size on shear strength of sand," Journal of Guangxi University, vol. 42, no. 4, pp. 1392-1398, 2017.

[79] J.-S. Lee, J. Dodds, and J. C. Santamarina, "Behavior of rigidsoft particle mixtures," Journal of Materials in Civil Engineering, vol. 19, no. 2, pp. 179-184, 2007.

[80] E. Q. Zhou, Q. Wang, and J. F. Lu, "Compressibility and shear properties of dry/saturated rubber sand," Journal of Civil and Envi Ronmental Engineering, vol. 41, no. 6, pp. 104-110, 2019.

[81] D. V. Okur and S. U. Umu, "Dynamic properties of cleand sand modified with granulated rubver," Advances in Civil Engineering, vol. 2018, Article ID 5209494, 11 pages, 2019.

[82] K. Senetakis, A. Anastasiadis, K. Pitilakis, A. Souli, T. Edil, and S. W. Dean, "Dynamic behavior of sand/rubber mixtures, part II: effect of rubber content on G/GO- $\gamma$-DT curves and volumetric threshold strain," Journal of ASTM International, vol. 9, no. 2, pp. 103711-1037112, 2012.
[83] A. Anastasiadis, K. Senetakis, and K. Pitilakis, "Small-strain shear modulus and damping ratio of sand-rubber and gravelrubber mixtures," Geotechnical and Geological Engineering, vol. 30, no. 2, pp. 363-382, 2012.

[84] M. T. Wu, F. C. Liu, and J. L. Chen, "Influence of water content on dynamic shear modulus and damping ratio of rubber-sand mixture under large strains," Rock and Soil Mechanics, vol. 39, no. 3, pp. 803-814, 2018.

[85] B. Li and M. S. Huang, "Dynamic triaxial tests on liquefaction characteristics of rubber-sand mixture," Rock and Soil Mechanics, vol. 38, no. 5, pp. 1343-1349, 2017.

[86] Y. Cheng, F. Liu, G. He et al., "Research on evolution law of dynamic pressure of rubber sand based on dynamic triaxial test," Building Structure, vol. 49, no. S2, pp. 873-877, 2019.

[87] E. Q. Zhou, Q. Wang, Z. X. Zong et al., "Cyclic triaxial tests on dynamic characteristics of saturated rubber-sand mixture," Rock and Soil Mechanics, vol. 40, no. 10, pp. 3797-3804, 2019.

[88] F. C. Liu, Y. F. Zhang, and L. Chen, "Experimental study on the influence of cycle numbers on dynamic properties of the geo-cell reinforced rubber-sand mixture," Journal of Hunan University of Technology, vol. 32, no. 3, pp. 23-29, 2018.

[89] M. Tajdini, A. Nabizadeh, H. Taherkhani, and H. Zartaj, "Effect of added waste rubber on the properties and failure mode of kaolinite clay," International Journal of Civil Engineering, vol. 15, no. 6, pp. 949-958, 2016.

[90] S. S. Li, D. Y. Li, and Y. K. Zhang, "Effects of scrap tire crumbs on compression behavior of clay," Journal of Shandong University of Science and Technology, vol. 35, no. 5, pp. 55-62, 2016.

[91] G. G. D. Ramirez and M. D. T. Casagrande, "Experimental study of granular rubber waste tire reinforced soil for geotechnical applications," Key Engineering Materials, vol. 600, pp. 585-596, 2014.

[92] J. S. Yadav and S. K. Tiwari, "Influence of crumb rubber on the geotechnical properties of clayey soil," Environment, Development and Sustainability, vol. 20, no. 6, pp. 25652586, 2017.

[93] P. T. Ravichandran, A. S. Prasad, K. D. Krishnan et al., "Effect of addition of waste tyre crumb rubber on weak soil stabilisation," Indian Journal of Science and Technology, vol. 9, no. 5, pp. 1-5, 2016.

[94] Z. Lu and K. S. Chen, "Experimental study on dynamic shear modulus and damping ratio of rubber clay mixture," Journal of Disaster Prevention and Mitigation Engineering, vol. 39, no. 2, pp. 250-257, 2019.

[95] J. He, Y. Li, and X. Ruan, "Strength properties of ground rubber of waste tire and clay mixtures," Chinese Journal of Rock Mechanics and Engineering, vol. 34, no. 2, pp. 43664372, 2012.

[96] S. S. Li and D. Y. Li, "Shearing properties of composite soil mixing clay with rubber particle of scrap tire," Journal of Yangtze River Scientific Research Institute, vol. 34, no. 7, pp. 99-105, 2017.

[97] H. J. Hou, K. X. Xue, Y. X. Hu et al., "Study of direct shear test on unstaurated clay mixed with rubber powder," Science Technology and Engineering, vol. 17, no. 3, pp. 293-297, 2017.

[98] J. Q. Dang and J. Li, "The structural strength and shear strength of unsaturated loess," Shui Li Xue Bao, vol. 2001, no. 7, pp. 79-83, 2007.

[99] Z. H. Li and H. Y. Zhang, "“Shear strength properties of waste tires' granulated rubber and loess mixtures," Rock and Soil Mechanics, vol. 33, no. 10, pp. 3013-3019, 2012.

[100] Z. J. Du and W. C. Liu, "Study on the shear volume strain characteristics of loess mixture with tire strips," Subgrade Engineering, vol. 205, no. 4, pp. 74-77, 2019. 
[101] Z. J. Du, W. C. Liu, and Y. Q. Yang, "Shear performance of large-size scrap tire strip-loess mixture," Journal of Yangtze River Scientific Research Institute, vol. 36, no. 9, pp. 125-130, 2019.

[102] Z. H. Li and H. Y. Zhang, "Compression properties of granulated rubber-loess mixtures as a fill materials," Applied Mechanics and Materials, vol. 71-78, pp. 673-676, 2011.

[103] A. Assadollahi, B. Harris, and J. Crocker, "Effects of shredded rubber tires as a fill material on the engineering properties of local memphis loess," in Proceedings of the Geo-Chicago 2016, Chicago, IL, USA, 2016.

[104] Z. P. Hu, Z. H. Liu, Z. Q. Zhang et al., "Test on influence of rubber powder on dynamic mechanic properties of manipulated Ioess," Journal of Chang'an University, vol. 33, no. 4, pp. 62-67, 2013.

[105] C. Y. Zuo, J. Zhou, and W. Deng, "A evaluate summarizing on reform effect of expansion soil admix rubber particles," Shanxi Architecture, vol. 36, no. 25, pp. 83-84, 2010.

[106] Y. C. Guo, Q. Xie, and Z. F. Zhan, "Experimental study on the Influence of water content on expansive soil properties," Subgrade Engineering, vol. 1, pp. 18-20, 2003.

[107] Z. Shen, Y. F. Wang, X. F. Kang et al., "A study of road performance on soil mixed with waste rubber tire particles," Journal of Nanjing Institute of Technology, vol. 16, no. 2, pp. 44-50, 2017.

[108] J. H. Carraro, E. Budagher, M. Badanagki et al., "Sustainable stabilization of sulfate-bearing soil with expansive soilrubber technology," Technical Report, Colorado Department of Transportation, Denver, CO, USA, 2013.

[109] H. Trouzine, M. Bekhiti, and A. Asroun, "Effects of scrap tyre rubber fibre on swelling behaviour of two clayey soils in Algeria," Geosynthetics International, vol. 19, no. 2, pp. 124-132, 2012.

[110] Y. Y. Wei, S. L. Sun, and H. Z. Zheng, "Laboratory tests on uniaxial compressive strength of expansive soil rubber (ESR)," Journal of Engineering Geology, vol. 18, no. 4, pp. 543-547, 2010.

[111] P. V. Kolhe and R. V. Langote, "Performance of black cotton soil stabilized with rubber tyre shreads," Journal of Geotechnical Studies, vol. 2, no. 2, pp. 1-8, 2018.

[112] J. Du, L. L. Xu, and L. J. Yang, "Laboratory test research on improving expansve soil with waste tire rubber powder," Road Engineering, vol. 98, no. 9, pp. 1-4, 2015.

[113] H. Elsaidy, W. M. Yan, and M. J. Pender, “A novel formula for the prediction of swelling pressure of compacted expansive soils," Géotechnique Letters, vol. 9, no. 3, pp. 231-237, 2019.

[114] A. Srivastava, S. Pandey, and J. Rana, "Use of shredded tyre waste in improving the geotechnical properties of expansive black cotton soil," Geomechanics and Geoengineering, vol. 9, no. 4, pp. 303-311, 2014.

[115] F. Zhang, "A study on the application of waste tire rubber in expansive soil," China Academic Journal Electronic Publishing House, vol. 248, no. 2, pp. 42-48, 2018.

[116] Y. Y. Wei, S. L. Sun, X. Zhang et al., "The shear strength relation between ESR and water conter," Journal of Engineering Geology, vol. 16, no. 5, pp. 612-616, 2008.

[117] J. M. Zong, Y. J. Song, Y. Lu et al., "Unconfined compressive strength test on expansive soil improved by waste tire rubber particles under freeze-thaw cycles," Journal of Yangtze River Scientific Research Institute, vol. 34, no. 9, pp. 110-114, 2017.

[118] B. R. Madhusudhan, A. Boominathan, and S. Banerjee, "Factors affecting strength and stiffness of dry sand-rubber tire shred mixtures," Geotechnical and Geological Engineering, vol. 37, no. 4, pp. 2763-2780, 2019.
[119] A. Panjamani, M. Mamatha, P. Soumyashree et al., "Laboratory characterization of tyre crumbs soil mixture for developing low cost damping materials," International Journal of Earth Sciences and Engineering, vol. 4, no. 6, pp. 63-66, 2011.

[120] B. R. Madhusudhan, A. Boominathan, and S. Banerjee, "Properties of sand-rubber tyre shreds mixtures for seismic isolation applications," in Book: Soil Dynamics and Earthquake Geotechnical Engineering, pp. 267-274, Elsevier, Amstersam, Netherlands, 2019.

[121] K. Pitilakis, S. Karapetrou, and K. Tsagdi, "Numerical investigation of the seismic response of RC buildings on soil replaced with rubber-sand mixtures," Soil Dynamics and Earthquake Engineering, vol. 79, pp. 237-252, 2015

[122] H. H. Tsang, "Uses of scrap rubber tires," in Rubber: Types," Properties and Uses, pp. 477-492, Nova Science Publishers Inc., New York, NY, USA, 2012.

[123] H. Hazarika, E. Kohama, and T. Sugano, "Underwater shake table tests on waterfront structures protected with tire chips cushion," Journal of Geotechnical and Geoenvironmental Engineering, vol. 134, no. 12, pp. 1706-1719, 2008.

[124] L. H. Li, Q. Ma, C. Y. Wang et al., "Triaxial test on mixture soil of waste tire granules and cement," Journal of Zhengzhou University, vol. 35, no. 4, pp. 33-35, 2014.

[125] W. Z. Yin, C. L. Shao, J. Zhou et al., "Experimental study on compression deformation properties of a new geogrid rein forced filler," Highway, vol. 63, no. 11, pp. 33-40, 2018.

[126] C. Q. Li and H. Y. Fu, "Analysis on displacement influence factors of reinforced earth in retaining structure," Highway, vol. 64, no. 7, pp. 16-208, 2019.

[127] A. Deng and J. R. Feng, "Experimental study on sandshredded tire lightweight fills," Journal of Building Materials, vol. 13, no. 1, pp. 116-120, 2010.

[128] A. Nakhaei, S. M. Marandi, and S. S. Kermani, "Effect of granulated rubber-soil mixture on reducing retaining walls displacement under earthquake forces," Applied Mechanics and Materials, vol. 94-96, pp. 3-17, 2011.

[129] S. Bali Reddy and A. Murali Krishna, "Mitigation of dynamic loading effects on retaining walls using recycled tire chips," in Book: Soil Dynamics and Earthquake Geotechnical Engineering, pp. 141-148, Elsevier, Amstersam, Netherlands, 2010.

[130] T. Tanchaisawat, D. T. Bergado, P. Voottipruex, and K. Shehzad, "Interaction between geogrid reinforcement and tire chip-sand lightweight backfill," Geotextiles and Geomembranes, vol. 28, no. 1, pp. 119-127, 2010.

[131] J. Seda, J. Lee, and H. Carraro, Beneficial Use of Waste Tire Rubber for Swelling Potential Mitigation in Expansive Soils, Geotechnical Special Publication, Auburn, IN, USA, 2007.

[132] Q. G. Yang and Y. F. Wang, "Study on road performance of waste rubber tire particles mixed expansive soil," Shan Xi Architecture, vol. 43, no. 36, pp. 99-101, 2017.

[133] V. Tiwari, A. Modi, and P. C. Diwan, "Soil stabilization using with waste crumb rubber tire," Journal for Innovative Development in Pharmaceutical and Technical Science, vol. 2, no. 5 , pp. $28-31,2019$.

[134] N. Hataf and M. M. Rahimi, "Experimental investigation of bearing capacity of sand reinforced with randomly distributed tire shreds," Construction and Building Materials, vol. 20, no. 10, pp. 910-916, 2006.

[135] G. Gill and R. K. Mittal, "Use of waste tire-chips in shallow footings subjected to eccentric loading-an experimental study," Construction and Building Materials, vol. 199, pp. 335-348, 2017. 
[136] Y. Liang, Z. Y. Hu, and L. L. Zhang, "Waste tyre reinforced high and steep seawall numerical simulation analysis," Port \& Waterway Engineering, vol. 526, no. 3, pp. 169-172, 2017.

[137] J. He, Y. Li, and X. Ruan, "Compaction performance of ground rubber and claymixtures," Journal of Engineering Geology, vol. 23, no. 5, pp. 1013-1019, 2015.

[138] K. Mukherjee and A. K. Mishra, "Hydraulic and mechanical characteristics of compacted sand-bentonite: tyre chips mix for its landfill application," Environment, Development and Sustainability, vol. 21, no. 3, pp. 1411-1428, 2018.

[139] J. H. Soltani, M. Asadzadeh, and V. Marefat, "Effects of tire chips on shrinkage and cracking characteristics of cohesive soils," Turkish Journal of Engineering and Environmental Sciences, vol. 37, pp. 259-271, 2013.

[140] K. Mukherjee and A. K. Mishra, "The impact of scrapped tyre chips on the mechanical properties of liner materials," Environmental Processes, vol. 4, no. 1, pp. 219-233, 2017. 